JOURNAL OF SECURITY AND SUSTAINABILITY ISSUES ISSN 2029-7017 print/ISSN 2029-7025 online

2019 December Volume 9 Number 2

http://doi.org/10.9770/jssi.2019.9.2(21)

Scopus

\title{
SECURITY OF THE EURASIAN ECONOMIC UNION MEMBER STATES: SOCIOECONOMIC AND FINANCIAL ASPECTS
}

\author{
Artem Krasnov', Bakyt Beknazarov ${ }^{2}$, Dinara Jarikbayeva ${ }^{3}$, Dinara Yeshpanova ${ }^{4}$, Alma Karshalova $^{5}$ \\ ${ }^{1}$ Kyrgyz-Russian Slavic University, 44 Kievskaya Str., Bishkek, 440000, Kyrgyz Republic \\ ${ }^{2}$ M.Auezov South Kazakhstan State University, 5 Tauke Khan Avenue, Shymkent, 160012, Republic of Kazakhstan \\ 3,4,5JSC "Narxoz University", 55 Zhandosov st., 1st micro district, 81 Almaty, 050035, Republic of Kazakhstan
}

Received 15 February 2019; accepted 10 November 2019; published 30 December 2019

\begin{abstract}
The Eurasian Economic Union (EAEU) system of the economic security is required to form the path of efficient development of the Common Economic Space (CES). The aim of the study is to quantify economic security and develop measures to ensure macroeconomic stability of the EAEU member states. The index estimation method, cross-country comparisons of indicators, and the expert ranking method were selected for research. The authors' method of calculating the integral index of economic security of an integration association has been presented, which includes three groups of indicators: development of the national economy, social and financial security. The results of the analysis have revealed that the highest level of economic security has been established in the Russian Federation and the Republic of Belarus. However, low GDP per capita in all EAEU countries, as well as low rates of GDP growth, production, industrial production, and value added in agriculture and gross capital formation in the largest EAEU member state - the Russian Federation, and a large volume of foreign currency borrowings in Belarus and Kyrgyzstan affect the level of economic security of the integration association. The most important threats to economic security have been identified as a result of expert ranking: tougher sanctions, depreciation of national currencies, and spontaneous migration processes. The results of the study allow the authors to conclude that measures must be developed to coordinate monetary policies, as well as to expand integration in the social and labor spheres.
\end{abstract}

Keywords: financial security, economic security, financial mechanism, state budget revenues, tax policy, foreign exchange policy, EAEU financial market

Reference to this paper should be made as follows: Krasnov, A., Beknazarov, B., Dinara Jarikbayeva, D., Yeshpanova, D., Karshalova, A. (2019). Security of the Eurasian economic union member states: socioeconomic and financial aspects, Journal of Security and Sustainability Issues 9(2): 637-648. http://doi.org/10.9770/jssi.2019.9.2(21)

JEL Classifications: 01

\section{Introduction}

The efficient development of the countries in the post-Soviet space is backed by integration processes, which are described by the achievement of an aggregate financial result based on the unification of the economic potentials of each member of the integration union in the economic aspect.

The collapse of the USSR led to the destruction of a single complex of traditional economic ties among the regions in the former republics and the emergence of crisis phenomena associated with the disintegration of the Soviet economy. The space for economic maneuver by various types of resources has narrowed as a result of the isolation of the economic systems of the CIS countries.

Creation and development of new independent states were accompanied by the emergence of threats to their national economic security, the most important of them being low competitiveness of economies, raw-materials export model of development (in Russia and Kazakhstan, in particular), technological backwardness, relative underdevelopment of business, instability of the financial system, unbalanced budgets, and a model of the national economy, characteristic of developing countries (Bulkhairova, 2019). 
In order to counter the risks and threats to national economic security, a system of integration ties began to form in the post-Soviet space. The EAEU was created in 2015 as a result of some initiatives aimed at achieving economic integration. The EAEU currently includes five former republics of the USSR: Russia, Kazakhstan, Belarus, Armenia, and Kyrgyzstan.

The priority areas of the EAEU economic development are ensuring macroeconomic stability of the member states, creating conditions for the growth of their business activity and investment attractiveness, increasing the availability of financial resources and the formation of a single financial market, and innovation-driven growth and modernization of the economy (Murashbekov, 2019).

The EAEU member states are currently faced with new risks and threats of loss of economic sovereignty, such as an increase in geopolitical risks, complication of geoeconomic situation, difficulties in interaction between independent states (Lipinsky, et al., 2019).

The further development of the national economies of the EAEU states becomes unpredictable without efficient mechanisms for economic integration and creates additional threats to the development of the integration association.

As such, the study of the socioeconomic and financial aspects of the security of each of the EAEU member states and the integration association as a whole is an urgent problem.

\section{Literature review}

The study is based on the theory and methods associated with the fundamental academic writings on the economic security issues. The international organization OECD notes that the economic policy of member states is the main idea of the security of integration association (OECD, 2019). The unified economic policy of the CES should integrate the elements of economic security of each EAEU member state (Czerewacz-Filipowicz, 2019).

Despite certain positive results in the study of this phenomenon, there is currently no unified, consistent scientific concept of economic security (Kulik, \& Petrenko, 2017; Moumen et al., 2019).

The problem is compounded by the fact that the phenomenon of economic security is systemic, multilevel and dynamic, and application of knowledge in various fields of science is required in the course of its study.

Several approaches to determining economic security can be defined based on the existing scientific developments.

- Using the "stability" term. According to this approach, the interpretation of the "economic security" concept implies a stable state of the economy, its security from external and internal threats. Proponents of this approach include Abalkin (1994), Afontsev (2012), Kormishkin et al. (2016), Petrenko (2012), Plotitsyna (2003), Glazyev (2010), Gerasimov et al. (2018).

- Using the "independence" term. Proponents of this approach interpret economic security as the state of social production that would allow to achieve economic sovereignty and ensure the ability of the national economy to constantly develop, update, and improve (Ronis, 2011; Ostapiuk, et al., 2017; Novoselova, et al., 2016; Ilyin, 2016; Karanina, \& Kartavyh, 2018; Gorodetsky, 2016).

The current state of the economy, which allows to determine and establish domestic policy in social, economic and other spheres without any significant external influences, can be considered the safest (Nam, et al., 2016).

- Using the "interests" term.

According to this approach, the stability of economic development and independence in any of the above understandings are included in the area of economic interests of the state (Shpilevskaya, 2016a). 
Proponents of this approach include A. Porokhovsky (2016), V. Senchagov (2017), A. Tatarkin and A. Kuklin, (2012), E. Shpilevskaya (2016b) et al., who associate the country's economic security with a state of the national economy that allows to ensure national-state interests.

Many writings are devoted to the study of certain aspects of the national economic security, including its relationship with the policy of import substitution (Burbina, 2019; Simanovskaya, \& Silanteva, 2016; Tetushkin, 2016), the study of sociocultural (Dyshaeva, 2019; Kostin, \& Kostina, 2013; Buranova, \& Getmanskaya, 2015), administrative, and legal aspects (Markina, 2016; Yerkeev, 2011; Fabuš, Csabay, 2018; Nikitina et al., 2018; Finogentova et al., 2018), the innovative component (Khan, 2018; Zakharkina, et al., 2018; Kozlova, 2009; Mikhaylov et al., 2018; Sagiyeva et al., 2018; Shevyakova et al., 2019), etc. Attempts were made in some writings to develop a system of measures that would take all the functional components of economic security into account, including the social and financial security of the state (Tsvetkov, et al., 2019; Batkovskiy et al., 2018; Gerasimov et al., 2018; Mackevičius et al. 2018).

As such, the considered approaches form the theoretical basis for the development of the national economic policies in individual countries. At the same time, it must be noted that the social and financial aspects of economic security currently remain poorly understood.

Besides, the need to take advantage of integration cooperation is growing in the context of globalization and aggravation of geopolitical risks in the post-Soviet space. This circumstance dictates the need for further research and development of conceptual directions for strengthening economic security within the EAEU integration association.

The goal of this study is to assess the level of economic security and study the social and financial aspects of stabilizing the macroeconomic situation of the EAEU member states.

It can be assumed that an important condition for strengthening the economic independence of the integration association is to improve cooperation in the monetary policy and to expand the integration of the EAEU countries in the social and labor spheres.

\section{Methods}

Three groups of sources were used to prepare the article, described by a high degree of reliability and relevance of information:

- Official publications of the Eurasian Economic Commission, the Eurasian Development Bank, the Analytical Center under the Government of the Russian Federation, national government bodies, and public organizations;

- Electronic databases of the World Bank, the UN, national statistical services, etc.

- Academic publications containing experimental research, collections of academic writings, monographs, conference proceedings, etc., and

- Regulatory framework and regulatory background information on the EAEU.

The index method of assessment and cross-country comparisons of economic security indicators are the main research methods.

The authors' method for calculating the integral index of economic security is proposed in order to measure the level of economic security of the EAEU member states.

The integral index $I$ is found using the following formula: 


$$
I_{e s}=\frac{I_{r s}+I_{s s}+I_{f_{s}}}{3}
$$

where

$I_{r s}$ is the index of the national economy development,

$I_{s S}$ is the social security index, and

$I_{f s}$ is the financial security index.

Each of the above indices is found using the following formula:

$$
I=\sum_{i=1}^{n} w_{i} * x_{i}
$$

where $w_{i}$ is the weight coefficient reflecting the significance of the $\mathrm{i}$-th partial indicator, and

$x_{i}$ is the normalized value of the $\mathrm{i}$-th partial indicator.

The principal component method was used to determine the weights, the advantage of it being the use of official statistics. All weights in this study were taken equal and found using the following formula:

$W=1 / n$, where $n$ was the number of partial indicators in the group.

The partial indicators are normalized in order to assess the degree of their remoteness from threshold criteria. This is done by finding the coefficient of achievement of the threshold criterion using the following formulas:

$\mathrm{Xi}=\mathrm{q}_{\mathrm{if}} / \mathrm{q}_{\mathrm{it}}$ for the case where a situation with the actual value of the indicator being not lower than the threshold value is considered safe, and

$\mathrm{Xi}=\mathrm{q}_{\mathrm{it}} / \mathrm{q}_{\mathrm{if}}$ for the case where a situation with the actual value being not higher than the threshold value is considered safe.

The threshold values are the average values of the indicators of the EU integration association. Threshold values for the indicators "annual deficit of the consolidated budget of the government sector" and "debt of the government sector" are accepted as those set in Article 63 of the Treaty on the EAEU.

In addition to quantitative assessment, an expert ranking method was used in order to identify threats to the economic security of the EAEU member states. The expert group consists of 20 experts with a high level of competence in matters of social, financial, and economic development of the EAEU. The questionnaire was used as the main method of the expert assessment. The assessment result is represented as a ranked series of major threats to the security of economic development.

\section{Results}

The Treaty on the EAEU entered into force in 2015, the main purpose of it being to strengthen national economies and member states and promote their sustainable economic growth.

The EAEU began to function in the context of a significant transformation of the world economy and the formation of new centers of economic development. Toughening global competition, reducing commodity and geographical markets, intensifying negative trends in sociodemographic development, increasing the importance 
of technological development as an essential factor for manifesting economic development opportunities, and reducing useful natural resources as one of the competitive advantages of countries all pose serious global challenges and jeopardize sustainable development of the EAEU member states.

At the same time, despite the persisting challenges and threats, as well as unfavorable foreign market situation, the EAEU member states pursue an active policy to strengthen their economic security and implement national socioeconomic development strategies.

The EAEU member states differ by the size of economy and growth rates. A significant difference in GDP is observed not only between the largest and smallest economies - Russian and Kyrgyz, but also between the Kazakh and Belarusian economies. For example, per capita GDP in Russia is 8.4 times higher than that of Kyrgyzstan, and 2.7 times higher than that of Armenia.

Indicators of the development of the real sector of the economy of the EAEU member states are shown in Table 1.

Table 1. Indicators of the development of national economies of the EAEU member states

\begin{tabular}{|c|c|c|c|c|c|c|c|}
\hline Indicator & Indicator type & Threshold value & Armenia & Belarus & Kazakhstan & Kyrgyzstan & Russia \\
\hline \multirow{2}{*}{$\begin{array}{c}\text { GNI per capita, Atlas method, } \\
\text { USD }\end{array}$} & Actual value & 35,359 & 4,230 & 5,670 & 7,830 & 1,220 & 10,230 \\
\hline & Normalized value & 1.00 & 0.12 & 0.16 & 0.22 & 0.03 & 0.29 \\
\hline \multirow{2}{*}{$\begin{array}{l}\text { Added value in agriculture } \\
\text { (annual increase in \%) }\end{array}$} & Actual value & 1 & -8.5 & -4 & 3.4 & 2.7 & -2 \\
\hline & Normalized value & 1.00 & 0.00 & 0.47 & 0.00 & 0.79 & 0.00 \\
\hline \multirow{2}{*}{$\begin{array}{l}\text { Added value in manufacturing } \\
\quad \text { (annual increase in \%) }\end{array}$} & Actual value & 1.7 & 2.2 & 5.1 & 4.2 & 6.2 & 2.9 \\
\hline & Normalized value & 1.00 & 1.00 & 1.00 & 1.00 & 1.00 & 1.00 \\
\hline \multirow{2}{*}{$\begin{array}{l}\text { Gross capital formation, } \\
\text { annual growth, } \%\end{array}$} & Actual value & 4.2 & 28.5 & 4.4 & 3.3 & 11.3 & 0.8 \\
\hline & Normalized value & 1.00 & 1 & 1 & 0.79 & 1 & 0.19 \\
\hline \multirow{2}{*}{$\begin{array}{l}\text { Expenditure for research and } \\
\text { development (\% of GDP) }\end{array}$} & Actual value & 2.03 & 0.23 & 0.59 & 0.64 & 0.11 & 1.1 \\
\hline & Normalized value & 1.00 & 0.11 & 0.29 & 0.32 & 0.05 & 0.54 \\
\hline \multicolumn{2}{|c|}{ National economy development index $I_{r s}$} & 1 & 0.45 & 0.58 & 0.46 & 0.58 & 0.40 \\
\hline
\end{tabular}

Source: compiled by the authors using the data from the World Bank (2019)

The Russian Federation holds a leading position in terms of per capita GDP among the EAEU member states. However, due to unfavorable external conditions (sanctions) and the current policy in Russia (increase in the VAT rate, pension reform), the index of the national economy development in 2018 was low.

Kyrgyzstan demonstrated the impressive dynamics of the growth rate of value added in manufacturing and agriculture as on the end of 2018.

Table 2 presents the results of the assessing social security indicators of the EAEU member states as on the end of 2018. 
Table 2. Social security indicators of the EAEU member states

\begin{tabular}{|c|c|c|c|c|c|c|c|}
\hline Indicator & Indicator type & Threshold value & Armenia & Belarus & Kazakhstan & Kyrgyzstan & Russia \\
\hline \multirow{2}{*}{ Gross savings ( $\%$ of GDP) } & Norm. & 23 & 14 & 29 & 26 & 27 & 30 \\
\hline & Actual & 1 & 0.61 & 1.00 & 1.00 & 1.00 & 1.00 \\
\hline \multirow{2}{*}{$\begin{array}{l}\text { Unemployment, total (\% of total } \\
\text { labor force) (according to ILO) }\end{array}$} & Norm. & 6.8 & 17.7 & 5.7 & 4.9 & 7.2 & 4.7 \\
\hline & Actual & 1 & 0.38 & 1.00 & 1.00 & 0.94 & 1.00 \\
\hline \multirow{2}{*}{$\begin{array}{c}\text { Share of the population living on less } \\
\text { than USD } 5.5 \text { (as of 2015) }\end{array}$} & Norm. & 3 & 50 & 1 & 9 & 66 & 3 \\
\hline & Actual & 1 & 0.06 & 1.00 & 0.33 & 0.05 & 1.00 \\
\hline \multirow{2}{*}{$\begin{array}{c}\text { Share of the working population, } \\
\text { total ( } \% \text { of the total population } \\
\text { aged } 15 \text { and older), } \%\end{array}$} & Norm. & 57 & 59 & 64 & 71 & 62 & 62 \\
\hline & Actual & 1 & 1.00 & 1.00 & 1.00 & 1.00 & 1.00 \\
\hline \multirow{2}{*}{$\begin{array}{l}\text { Coefficient of age dependence } \\
\text { (\% of the elderly in the } \\
\text { working population) }\end{array}$} & Norm. & 31 & 17 & 22 & 11 & 7 & 22 \\
\hline & Actual & 1 & 0.55 & 0.71 & 0.35 & 0.23 & 0.71 \\
\hline Social security index $I_{r s}$ & & 1.00 & 0.52 & 0.94 & 0.74 & 0.64 & 0.94 \\
\hline
\end{tabular}

Source: compiled by the authors

The state budget surplus was observed in Belarus, Kazakhstan, and Russia in 2018. The budget deficit was 1.6 $\%$ of GDP in Armenia and $0.3 \%$ in Kyrgyzstan. At the same time, the revenues of the national budgets of most EAEU member states demonstrated substantial growth in 2018. The budget revenues grew by $8.3 \%$ in Armenia, by $116.8 \%$ in Belarus, by $0.5 \%$ in Kyrgyzstan, and by $19.7 \%$ in Russia. Revenues of the national budget of the Republic of Kazakhstan decreased by $13.7 \%$.

An increase in budget expenditures was observed only in the Republic of Belarus in 2018. The budgetary expenditures decreased by $4 \%$ in Armenia, by $6.6 \%$ in Kyrgyzstan, by $5.4 \%$ in Russia, and by as much as 18.1 $\%$ in Kazakhstan in 2018.

All member states of the Union ensured that the state levels were in compliance with the limit quantitative value of the inflation rate established by the Treaty on the EAEU within $107.5 \%$ in 2018 . The size of public debt exceeded the threshold level of $50 \%$ in two out of five countries (Armenia and Kyrgyzstan), the main reason being a sharp weakening of national currencies. The lowest level of financial security was observed in the Kyrgyz Republic.

The results of calculating the integral index of economic security indicate that the Russian Federation and the Republic of Belarus occupy the strongest positions among the EAEU member states (Figure 1). The economies of Armenia and Kyrgyzstan are the most vulnerable. 


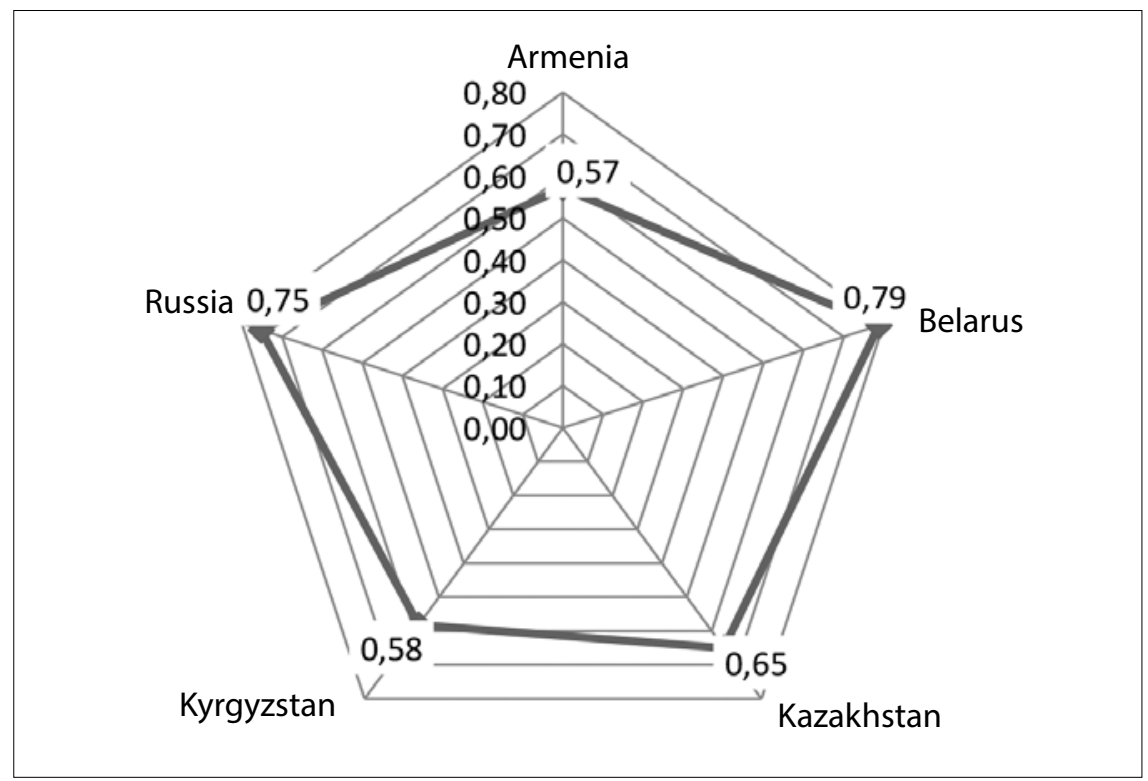

Fig. 1. Integral indicator of economic security of the EAEU member states

Source: compiled by authors

The questionnaire of experts has revealed threats to the economic security of the EAEU member states (Figure 3), the main ones being tougher sanctions, depreciation of national currencies, and spontaneous migration processes.

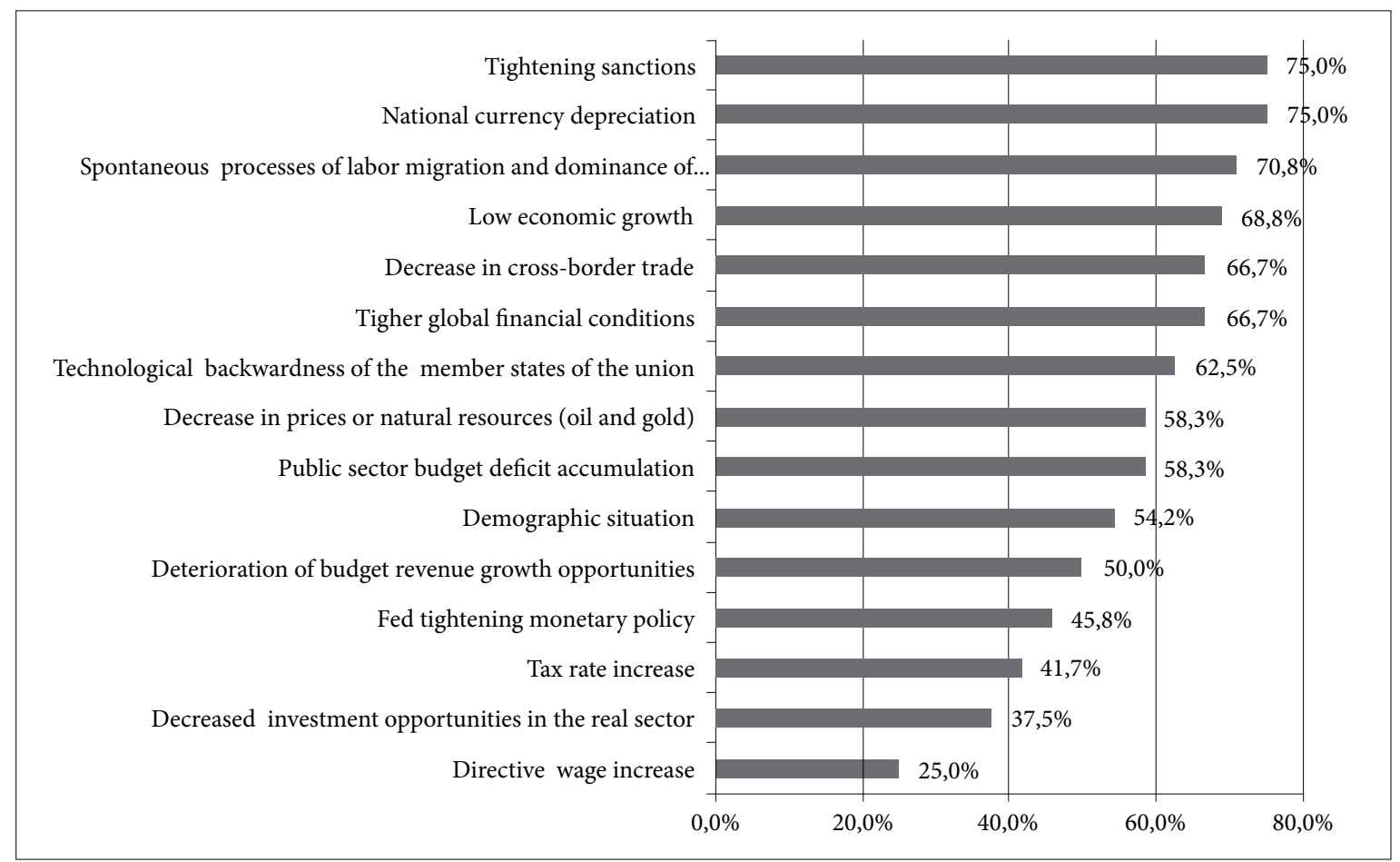

Fig. 2. Ranking of common threats to the economic security of EAEU member states

Tightening sanctions rhetoric by the US and the EU against the Russian Federation may lead to further depreciation of the ruble, capital outflows, higher inflation, problems in the financial sector, and a reduction in foreign trade (Sayfieva, et al., 2019). 
According to the experts, instability of the national currencies in the EAEU member states is the second most important threat to the economic security of the integration association. Due to the high share of foreign currency in the balance of payments in the largest national corporations and the savings of the population, sharp fluctuations in the exchange rate of the national currency can undermine the price and income system and the operation of national financial and banking systems.

An unfavorable demographic situation and spontaneous migration processes in the labor market are also a significant threat to economic security. This phenomenon represents a danger of increased criminalization of the economy and social differentiation of the population of the EAEU member states.

\section{Discussion}

The successful formation of a common EAEU market largely depends on many factors, including the social and financial aspects of economic security. As such, the economic security of countries largely depends on the terms of trade within the countries of the union, which, in turn, directly depend on the exchange rate, interest rate, and inflation.

The experts participating in the survey believe that the EAEU member states need to achieve progress in three areas in order to coordinate monetary policies: reduce inflation, increase dedollarization, and strengthen national currencies. The authors consider it important to clarify the term "dollarization". This is a phenomenon of the international monetary market, where foreign currency (most often USD) is widely used for operations within the country or certain regions of the world, up to the complete replacement of the national currency. Accordingly, dedollarization is the reverse process.

The problems of dependence of the EAEU member states on dollarization were explored in the expert discussion "Dedollarization in the EAEU member states: practice and prospects" held on March 29, 2018. The experts noted that the issue of the USD dominance in the global financial system was increasingly gaining political importance - the US currency was a powerful tool to influence all countries without exception and economic entities of the whole world (Valdai Discussion Club, 2018). The issue of reducing dependence on the USD is becoming a key condition for successful independent development in an era when economic sanctions and the manipulation of financial flows have become a lever not only of competition, but also of political pressure.

At the same time, some experts agree that favorable background for the active promotion of dedollarization has been established in the EAEU member states: economic growth and trade turnover are recovering, largely driven by investment growth. Although the economies of the EAEU member states are still described by a high degree of financial dollarization, various control measures applied in the member states of the union have already yielded some progress and a decrease in dependence on the USD. This, in turn, can contribute to the rapprochement of monetary policies of the states and further deepen integration within the EAEU.

A high level of dollarization has been a characteristic feature of the EAEU member states over the past 30 years: for example, the share of deposits in foreign currency was between $41 \%$ and $70 \%$ in $2015-2016$. This was due to a high inflation rate, a long period of using a fixed exchange rate, and frequent periods of financial instability. The share of deposits in foreign currency in the total volume of the EAEU broad money supply has significantly decreased since 2016 . For example, dollarization decreased from $72 \%$ to $60 \%$ rate in the Republic of Belarus, from $42 \%$ to $27 \%$ in Russia, and from $51 \%$ to $31 \%$ in the Republic of Kazakhstan.

According to Alexander K. (senior economist in the bank, survey participant), positive changes occurred due to a series of measures taken by central banks and governments of these countries. The expert notes that these measures should continue: national currencies should be used more in government borrowing, macroeconomic environment should improve, and foreign financing should be replaced with domestic. As for the EAEU member states, active mutual trade will also contribute to this (Ananiev, et al., 2019). 
Other experts believe that dollarization and dedollarization are not linear but cyclical, since the economies of the leading EAEU member states - Russia and Kazakhstan - are highly dependent on fluctuations in oil prices: national currencies depreciate as oil prices fall. According to the experts, extensive economic integration involving countries whose economies are not dependent on commodity prices, such as India and China, is an efficient measure to combat dependence on the USD.

The growth of domestic trade is a prerequisite for improving the economic security of the EAEU member states. However, some problems exist: an uneven distribution of both volumes and growth of trade within the union (Russia being the leader), a disproportionate focus on foreign markets, and a reliance on oil and gas resources. Along with other factors, this presents the union with many challenges that it will have to deal with in the coming years.

In order to increase domestic trade between the EAEU member states, the work on removing the existing barriers should be continued, thereby moving towards the formation of common markets for services, capital, and labor.

Expanding the integration of the EAEU member states in the social and labor areas becomes an urgent task in this context. A legal framework has been developed that regulates the simplified procedure for the adoption of citizenship and border crossing, creation of equal conditions for social security and medical services for labor migrants, and accounting for the employment records. The agreements on the mutual recognition of documents on education and the formation of preferential conditions for the development of small and medium enterprises, etc. have been concluded.

The EAEU member states have already felt the consequences of removing barriers to the labor market. For example, labor migrants from Kyrgyzstan and Armenia have become more competitive when applying for jobs in Russia and Kazakhstan. Unlike migrants from other countries, they do not need to obtain a work permit. Labor migrants from the EAEU member states are entitled to receive medical care and some social benefits in the countries of stay.

At the same time, the issue of implementing the pension rights of labor migrants from the EAEU member states remains a problem. Significant differences in the pension systems of the Union member states is the main reason for this.

The experts note that not all EAEU member states form pension rights for workers at the moment (E. Gulmadova, Head of the Social Protection Department of the Eurasian Economic Commission). Their formation has been provided for by the legislation of the Republic of Armenia and the Russian Federation since 2014 and by the Republic of Belarus since 2016. They apply to citizens with a status of temporary residents.

The pension rights of temporarily staying labor migrants are not being formed in the Republic of Kyrgyzstan, i.e., contributions to Pension Funds are not paid for them. Besides, there is no mechanism for transferring a pension even though the legal framework is established. As a result, the worker who has worked for a few years in another state of the Union, does not receive their pension in full after returning to the homeland and applying for it.

The work is currently underway to develop an agreement on the provision of pensions for workers as part of the creation of a single labor market for the EAEU. This agreement will allow them to form, maintain and further realize their pension rights that were formed in the state of the Union they worked in.

It must be noted that the pension agreement was designed in such a way that national pension systems were not changed. The issues of ensuring the preservation of the transfer of pension rights in case of relocation within the union are the key norms of this document. The experts note the importance of legitimate employment, since illegal labor migration leads to a lack of conditions for the pension rights formation. 
As such, this agreement will ensure social protection and the right to a pension to citizens who temporarily work in the territory of another EAEU member state in accordance with the national legislation.

\section{Conclusion}

The results obtained in the course of the study allow to draw the following conclusions:

- The highest level of the economic security among considered countries is observed in the Russian Federation and Belarus. However, low growth in both value added in agriculture and gross capital formation weaken the macroeconomic stability of these countries;

- Extensive foreign currency borrowings have led to a sharp increase in government debt in percentage of GDP in the national currency. At the same time, this indicator remains low in the two largest countries of the EAEU - Russia and Kazakhstan, which ensures macroeconomic stability for the whole association.

- The main threats to the economic security of the EAEU member states have been identifie based on the results of an expert assessment: toughening sanctions, depreciation of national currencies, and spontaneous migration processes.

- It is necessary to develop and implement a number of measures aimed at reducing inflation, dedollarization and strengthening the national currencies of the EAEU member states in order to coordinate monetary policies.

- The growth of domestic trade is a necessary condition for improving the economic security of the EAEU member states. This necessitates the development of measures to expand the integration of the EAEU countries in the social and labor areas.

One of the significant barriers to the creation of a common labor market in the EAEU is the lack of legal mechanisms for implementing the pension rights of labor migrants from the EAEU member states.

\section{References}

Abalkin L. I. (1994). Economic Security of Russia: Threats and Their Reflection]. Voprosy ekonomiki, 12, 4-13.

Afontsev, S. A. (2012). From the customs Union to the Common economic space: opportunities and risks. ECO, 6, 94-112.

Ananiev, M. A., Burlankov, S. P., Melnikova, D. M., \& Sedova, N. V. (2019). Forecasting the Main Indicators of Food Security of Russia. International Journal of Recent Technology and Engineering (IJRTE), 8(2), 4637-4642.

Batkovskiy, A.M., Efimova, N.S., Kalachanov, V.D., Semenova, E.G., Fomina, A.V., Balashov, V.M. (2018). Evaluation of the efficiency of industrial management in high-technology industries. Entrepreneurship and Sustainability Issues, 6(2), 577-590. http://doi. org/10.9770/jesi.2018.6.2(8)

Bulkhairova, et al. (2019). The Situation of Food Security in Kazakhstan. Space and Culture, 7(1), 194-205. Retrieved October 24, 2019, from http://spaceandculture.in/index.php/spaceandculture/article/view/469/282

Buranova, E. A., \& Getmanskaya A. D. (2015). Social policy in the strategy of economic security. Scientific-methodical electronic journal "Concept", 13, 3811-3815.

Burbina, A. A. (2019). The Relationship of import substitution policy and the level of economic security of the Russian Federation. Young scientist, 21, 170-174.

Czerewacz-Filipowicz, K. (2019). The Eurasian Economic Union as an Element of the Belt and Road Initiative. Comparative Economic Research, 22(2), 23-37. Retrieved October 24, 2019, from https://www.scopus.com/inward/record.uri?eid=2-s2.085068321396\&doi $=10.2478 \% 2$ fcer-2019-0010\&partnerID=40\&md5=ab415a053d280841cd6f11188634d124

Dyshaeva, L. (2019). Prospects for the reproduction of Human Capital and ensuring the economic security of the state in the Russian Federation. IOP Conference Series: Earth and Environmental Science, 272(3), 032211.

Fabuš, M., Csabay, M. (2018). State aid and investment: case of Slovakia. Entrepreneurship and Sustainability Issue, 6(2), $480-488$. http://doi.org/10.9770/jesi.2018.6.2(1)

Filipishyna, L., Bessonova, S., Venckeviciute, G. (2018). Integral assessment of developmental stability: cases of Lithuania and Ukraine. Entrepreneurship and Sustainability Issues, 6(1), 87-99. http://doi.org/10.9770/jesi.2018.6.1(7) 
Finogentova, O., Tokarev, V., Petrenko, M., Primak, T. (2018). Acceptance criterion of state coercion in contemporary society. Entrepreneurship and Sustainability Issues, 6(2), 820-829. http://doi.org/10.9770/jesi.2018.6.2(23)

Gerasimov, B.N., Vasyaycheva, V. A., Gerasimov, K.B. (2018). Identification of the factors of competitiveness of industrial company based on the module approach. Entrepreneurship and Sustainability Issues, 6(2), 677-691. http://doi.org/10.9770/jesi.2018.6.2(15)

Glaz'ev, S. Yu. (2010). Strategiya operezhayushchego razvitiya Rossii v usloviyakh global'nogo krizisa [Strategy of Russia's Advanced Development in the Global Crisis Context]. Moscow: Ekonomika.

Gorodetsky, A.Ye. (2016). Government Administration and Economic Security. About the Dysfunctions of Government Administration. Audit and Financial Analysis, 6, 426-437.

Ilyin, V. N. (2016). Economic security in the national security system of the Russian Federation. Economics, 50-1.

Karanina, E., \& Kartavyh, K. (2018). Economic security of modern Russia: The current state and prospects. MATEC Web of Conferences, 170,01003 .

Khan, M. Y. H. (2018). The Effectiveness of Entrepreneurial Activities for Economic Development: A Route to Innovation and Job Generation. Socioeconomic Challenges, 2 (2), 32-40.

Kormilkin, E. D., Causewa, O. S., \& Fedonin, O. V. (2016). The Economic security of the region. Saransk: Print-Published.

Kostin, V. I., \& Kostina, A.V. (2013). National security of modern Russia: economic and socio-cultural aspects. Moscow: LIBROKOM. Kozlova, A. (2009). Economic security as a phenomenon and concept. Authority, 1, 14-17.

Kulik, A. M., \& Petrenko, S. A. (2017). Metody otsenki ugroz ekonomicheskoy bezopasnosti regiona [Methods of assessing threats to the economic security of the region]. Aktualnyye Problemy I Perspektivy Razvitiya Ekonomiki V Usloviyakh Modernizatsii [Relevant Problems and Prospects for Economic Development in The Context of Modernization], 81-84.

Lipinsky, D. A., Musatkina, A. A., Stankin, A. N., \& Chuklova, E. V. (2019). Corruption Risks as a threat to the national security: A comparative analysis of their prevention and minimization. Amazonia Investiga, 8(20), 354-364.

Mackevičius, J., Šneidere, R., Tamulevičienè, D. (2018). The waves of enterprises bankruptcy and the factors that determine them: the case of Latvia and Lithuania. Entrepreneurship and Sustainability Issues, 6(1), 100-114. http://doi.org/10.9770/jesi.2018.6.1(8)

Markina, I. A. (2016). Administrative-legal mechanism of economic security system of the country. Actual Problems of Economics, 183(9), 69-76.

Mikhaylov, A.S., Mikhaylova A.A., Savchina, O.V. (2018). Innovation security of cross-border innovative milieus. Entrepreneurship and Sustainability Issues, 6(2), 754-766. http://doi.org/10.9770/jesi.2018.6.2(19)

Moumen, Z., El Idrissi, N.E.A., Tvaronavičienė, M., Lahrach, A. (2019). Water security and sustainable development. Insights into Regional Development, 1(4), 301-317. https://doi.org/10.9770/ird.2019.1.4(2)

Murashbekov, O. (2019). Challenges on Introducing Information Security Standards: A Case Study. Journal of Security and Sustainability Issues, 8(4), 665-674. Retrieved October 24, 2019, from https://jssidoi.org/jssi/papers/papers/view/370

Nam, Y., Lee, Y., McMahon, S., \& Sherraden, M. (2016). New Measures of Economic Security and Development: Savings Goals for Short- and Long-Term Economic Needs. Journal of Consumer Affairs, 50(3), 611-637.

Nikitina, M.G., Pobirchenko, V.V., Shutaieva, E.A., Karlova, A.I. (2018). The investment component in a nation's economic security: the case of the Russian Federation. Entrepreneurship and Sustainability Issues, 6(2), 958-967. http://doi.org/10.9770/ jesi.2018.6.2(32)

Novoselova, N. N., Krasnyuk, L. V., Sukhorado, Y. A., Dzagoyeva, M. R., \& Aylarova, Z. K. (2016). Factors of providing food and economic security of the state and its regions. International Review of Management and Marketing, 6(1), 159-164.

Official website of the Organisation for Economic Cooperation and Development, OECD. Retrieved October 24, 2019, from http:// www.oecd.org/

Ostapiuk, N., Karmaza, O., Kurylo, M., \& Timchenko, G. (2017). Economic security in investment projects management: convergence of accounting mechanisms. Investment Management and Financial Innovations, 14(3), 353-360.

Petrenko, I. N. (2012). The Essence of the definition of "security of economic space", its components and basic factors. Economics, statistics and Informatics. Bulletin UMO, 5, 79-82. 
Ploticyna, L. A. (2003). Theoretical and methodological aspects of economic and social security of Russia. Finance and credit, 20, $18-24$.

Porokhovsky, A. A. (2016). Political economy in the XXI century (a reliable key to the system analysis of the modern economy and the solution of its problems). Special English-language edition of magazines Questions of political economy and economic revival of Russia, 58-74.

Ronis, S. R. (ed.) (2011). Economic Security: Neglected Dimension of National Security? Washington, DC.

Sagiyeva, R,, Zhuparova, A., Ruzanov, R., Doszhan, R., Askerov, A. (2018). Intellectual input of development by knowledge-based economy: problems of measuring in countries with developing markets. Entrepreneurship and Sustainability Issues, 6(2), 711-728. http://doi.org/10.9770/jesi.2018.6.2(17)

Sayfieva, S. N., Shakhov, O. F., Nevmyvako, V. P., Chernavsky, M. Y. \& Vysotskaya, N. V. (2019). Taxation in the Context of Economic Security: Opportunities and Technologies. International Journal of Recent Technology and Engineering (IJRTE), 8(2), 6089-6094.

Senchagov, V. K. (2017). Economic security of Russia: General course. Moscow: BINOM. Knowledge laboratory.

Shevyakova, A., Munsh, E., Arystan, M. (2019). Information support for the development of tourism for the diversification of the economy of Kazakhstan. Insights into Regional Development, 1(2), 138-154. https://doi.org/10.9770/ird.2019.1.2(5)

Shpilevskaya, E. V. (2016a). Economic security of the country: threats and ways to ensure it. International research journal, 5-1, 188-193.

Shpilevskaya, E. V. (2016b). Ekonomicheskaya bezopasnost' strany: ugrozy i puti yeye obespecheniya [The economic security of the country: threats and ways to ensure it]. International Research Journal, 5-1, 188-193.

Simanovskaya, M. L., \& Silanteva, E.S. (2016). Import substitution of economic theories. Public Adm.E-J., 56, $198-219$.

Tatarkin, A. I., \& Kuklin, A. A. (2012). Izmenenie paradigmy issledovanij jekonomicheskoj bezopasnosti regiona [The Paradigm Shift in the Region's Economic Security Research], Economy of the region, 2, 25-39.

Tetushkin, V. A. (2016). Marketing analysis of import substitution within the food embargo: aspects of economic security of the Russian Federation. Agro Prod. Economic. J., 8, 13-41.

The World Banks. (2019). Indicators. Retrieved October 24, 2019, from https://data.worldbank.org/indicator

Tsvetkov, V. A., Dudin, M. N., \& Lyasnikov, N. V. (2019). Analytical approaches to estimate economic security of the region. Economy of Region, 15(1), 1-12.

Valdai Discussion Club (2018). De-Dollarization in the EAEU: Experience and Prospects. Expert Discussion. Retrieved October 24, 2019, from http://ru.valdaiclub.com/events/announcements/dedollarizatsiya-eaes/

Yerkeev, I. Kh. (2011). On some problems of ensuring of the Russian Federation. The Rule of Law State: Theory and Practice, 3(25), $76-80$.

Zakharkina, L., Myroshnychenko, I., Smolennikov, D., \& Pokhylko, S. (2018). Efficiency of innovation activity funding as the driver of the state's national economic security. Montenegrin Journal of Economics, 14(4), 159-173.

\section{Artem KRASNOV}

ORCID ID: 0000-0002-6564-8911

\section{Bakyt BEKNAZAROV}

ORCID ID: 0000-0002-0518-2398

Dinara JARIKBAYEVA

ORCID ID: 0000-0002-2336-9690

Dinara YESHPANOVA

ORCID ID: 0000-0003-3215-5122 